\title{
CONTEXTUAL, REVELANT AND PRACTICAL CHEMISTRY TEACHING AT UPPER SECONDARY SCHOOL LEVEL TEXTBOOKS IN FINLAND
}

\author{
Veli-Matti Ikävalko \\ Unit of Chemistry Teacher Education, Department of Chemistry, University of Helsinki \\ veli-matti.ikavalko@helsinki.fi \\ Maija Aksela \\ Unit of Chemistry Teacher Education, Department of Chemistry, University of Helsinki \\ maija.aksela@helsinki.fi
}

\begin{abstract}
Contextual teaching approaches can motivate students, make chemistry learning more relevant and affect the students' career choices later in life. This article presents the needs analysis section of a design research project. This needs analysis focused on the instructions for experimental tasks ( $\mathrm{N}=160$ ) found in Finnish upper secondary school textbooks and the STS (Science-TechnologySociety) and everyday chemistry content in these instructions. It was found that the studied content can be divided into three levels: (II) context-based experiment instructions, (I) indirect contextual references and (0) no context. Over one third of the experiment instructions (37.5\%) did not contain any context whatsoever. The content that did have a context mostly dealt with household chemistry related to everyday phenomena such as food and foodstuffs. The second most common themes in the instructions were: environment and nature and industry, technology and production. Most of the instructions were "recipe-like" and on the first level of Gilbert's context model. In terms of relevance, most of the studied instructions focused on the individual level. In the future, experiment instructions should be developed to be more relevant at school level.
\end{abstract}

\section{Introduction}

Context-based teaching, where the content consists of everyday phenomena, achieves better learning results, improves students' motivation to learn and increases their interest in chemistry (e.g., Gilbert 2006, Bennett \& Lubben 2006, Ültay \& Çalik 2012, Kuhn \& Muller 2014). The concept of context in experiment-based chemistry teaching has been a special point of focus in many countries and in such programmes as (i) the Salters' programme in the United Kingdom (Bennett \& Lubben 2006), (ii) the Industrial Chemistry programme in Israel (Hofstein \& Kesner 2006) and the Chemistry in Practice programme in the Netherlands (Bulte \& al. 2006). The Chemistry in Practice programme, for example, managed to increase student motivation in a water-related project. The students felt that they were doing something that was relevant to them and found feelings of inner autonomy in the fact that the work was not donemerely to please the teacher. The students also found working on the experiments to be pleasant (Bulte \&al. 2006).

As research subjects, textbooks provide an overall view of the current state of contextbased chemistry teaching. Textbooks provide opportunities to approach a topic from many angles: (a) science as a body of knowledge, (b) science as a way of investigating, (c) science 
as a way of thinking, (d) the interaction between science, technology and society (Wilkinson 1999) and chemistry from the perspective of the nature of science (e.g., Vesterinen \&al. 2011). This study aims to discover what sort of everyday chemistry contexts are present in the experiment instructions found in Finnish upper secondary school chemistry textbooks. The instructions are also discussed in terms of their relevance. Most Finnish teachers use the experiments found in the textbooks in their work (Lavonen \&al. 2005).

\section{Relevance in chemistry teaching}

A large study called ROSE, or the Relevance of Science Education, has been conducted on young people in Europe. This study measured European youth's interest in studying chemistry and in the different areas of chemistry. The part of the study that focused on Finnish youth (Lavonen \& al. 2005) indicated that they show very limited interest towards chemistry-related phenomena. Instead, the youth were interested in decision-making, opportunities to make a difference, helping others and developing oneself, and considered these issues to be more relevant to them.

It is important to better accommodate relevance in chemistry teaching in the future. The "need-to-know" theme is part of the international educational discourse and it is exerting pressure on educational policy makers and curricula planners (Stolk \&al. 2009 Ültay \&Çalik 2012).

The concept of relevance is a complex one, however. One can ask: "relevant to whom?" or "why is something relevant?" Every young person lives in their own world and has their own worldview. Interests and values change from moment to moment. There is no single right theme or approach. It is telling that students' attitudes and what they consider important vary depending on which part of society they belong to. Aikenhead (2003) has collected some of the different perspectives on this topic: What and how should students be taught about science?

1. Academic circles: "I wish they knew more about science" (wish-they-knew science)

2. Curriculum makers and researchers: "There is a need to generally know more about science" (need-to-know science)

3. Industry and professionals: "There should be more functional science" (functional science)

4. Media: "Let us get them excited about science" (enticed-to-know science)

5. Economists: "There must be a reason to study science" (have-cause-to-know science)

6. Cultural circles: "Science is a part of culture" (science-as-culture)

7. Students: "Personal interest in science" (personal-curiosity science)

What these different perspectives illustrate is that different operators define relevance each in their own way. Each has their own motives that stem from their own interests. The ones mentioned above are only examples of the dozens of different operators there are. 
One way to grasp the concept of relevance is to use different dimensions. Stuckey, Hofstein, Mamlok-Naaman \& Eilks (2013) have created three dimensions for relevance by combining previous relevance theories. These three dimensions are:

1. Individual dimension, which includes the individual's personal interests

2. Societal dimension, where the individual operates as part of a community

3. Vocational dimension, where the individual aims to fulfil the requirements of professional life

In this theory, each dimension also takes into acoount the temporal aspect: what is relevant today and what might become relevant in the future. The theory also contains perspectives inside and outside of the individual, bringing forth both personal and social interests.

On the individual level, a person creates their own reasons why they want to know more about science. These may include learning practical skills that are useful in everyday life or motivations related to studies now or in the future (Stuckey et al., 2013).

On the societal level, a person functions responsibly in society, makes sustainable choices and participates in societal affairs. The connection between society and science is also understood (Stuckey et al., 2013).

The vocational level answers the following question related to motivation and relevance: "What am I going to be when I grow up?" This level encompasses growing into a profession, choosing a career and weighing different specialisation options (Stuckey et al., 2013).

\section{Contexts in chemistry teaching}

Contextuality also takes multidimensional forms. Contexts may be present in the taught content either extensively or to a lesser degree. Approaches to contexts depend on the goals and the contents. In his article, Gilbert (2006) contemplated different models for contexts. He presented four different context levels where knowledge, content and the actor are in mutual interaction.

1. On the first level, knowledge and the application of knowledge are engaged in one dimensional interaction. On this level, knowledge directly results in an application, which the actor then performs. Example: an indicator shows that the $\mathrm{pH}$ of a vinegar solution is below 7 , therefore the solution is acidic.

2. On the second level, knowledge and the application of knowledge are engaged in reciprocal interaction. On this level, the actor approaches the situation from several different premises and knowledge bases. Example: the acidity of acetic acid may be approached via molecular structure, oxidation of ethanol into carboxylic acid, measurement automation, etc.

3. On the third level, knowledge, its application and the processor of the knowledge, i.e., the actor, interact with each other. This level also incorporates the human dimension, meaning that the student's own thoughts are also expressed. 
4. On the fourth level, knowledge, its application, the processor of the knowledge and the social environment interact with each other. Levels three and four involve higher order thinking skills.

Today, there are two prominent context-based approaches to science teaching:

1. Science, Technology and Society, or STS

2. Socio-Scientific Issues, or SSI

In both of these approaches, humans are active operators and interact with their living environments in their daily lives. In this context it is appropriate to talk about everyday chemistry, for example.

STS contexts freely combine the three elements (science, technology and society) and move within them and createlinks between them. STS enables the use of themes rising from people's daily lives, professional life and societal issues. The STS approach is on the third level of Gilbert's (2006) context model, where knowledge, the application of the knowledge and the processor of the knowledge interact with each other. This level also involves the human dimension, meaning that the student's own thoughts are also expressed. The letter $\mathrm{E}$ for Environment may be added to the acronym STS to create STSE. STS teaching aims to create links between science, technology and society and to promote environmental perspectives. STS is nearest to Gilbert's levels two and three.

The SSI approach is on level four of Gilbert's model, where knowledge, its application, the processor of the knowledge and the social environment interact with each other. SSI places emphasis on interactive discussion. In learning situations, SSI tasks deal with complex societal challenges and decision-making, such as the topic of climate change. Science-based discussion and argumentation are more important in SSI than right answers. In complex situations, when someone benefits, someone else is hurt. Open tasks are typical of SSI.

SSI has yielded positive experiences in teaching complex themes in chemistry (e.g., Hofstein \& al. 2010), but SSI approaches must be very structured to compensate for the openness (J untunen \&Aksela 2014).

This study discusses contexts from an STS perspective. Aikenhead (1994) defines levels for STS teaching based on how they could be used in teaching situations with different content emphases. These levels form a direct continuum from teaching pure theoretical scientific knowledge to pure STS learning, where theoretical knowledge is already incorporated into the discussion. On the last step (8), learners are ready to make decisions, for example, because their theoretical knowledge is already that advanced. Aikenhead's eight levels of STS are:

1. Motivation by STS content. At this level, there are small references to STS themes, but they are not focused on.

2. Casual infusion of STS content. STS references, which mostly require remembering information, are casually introduced into the learning.

3. Purposeful infusion of STS content. This level already requires some understanding of the connection between scientific knowledge and STS content. 
4. Singular discipline through STS content.

5. Science through STS content.

6. Science along with STS content.

7. Infusion of science into STS content.

8. Pure STS content.

\section{Study: need analysis of study material}

\subsection{Research method}

This case study is part of a design research project (Edelson 2002) where the aim is to use research to create contextually relevant experiment instructions for upper secondary school chemistry in co-operation with the business sector. This design research project is conducted as part of a doctoral dissertation and the case study presented in this article serves as the need analysis section of the project. The aim is to discover what the current status of contextuality is in the experiment instructions in Finnish chemistry teaching.

The content analysis of this study focuses on the experiment instructions found in upper secondary school textbooks used in chemistry teaching. The contexts found in Finnish textbooks have not been previously studied, which makes this analysis useful in supporting the development of teaching.

The main research question is to discover how the context of everyday chemistry is present in the textbooks' experiment instructions and what sort of themes they discuss. The instructions are also analysed from the perspective of relevance theory.

In this study, contexts are defined by the STS approach (Aikenhead 1994) and "everyday chemistry". They denote personal, social and technological situations where science, everyday chemistry in particular, is present. All events and phenomena related to people's lives, living habits, living environment and actions found in the experiment instructions are analysed.

Conducting the actual experimentation work, which is important for developing chemistry skills and pure theoretical knowledge are not included in this study.

Experiment instructions are considered to be context-based if they first describe a theme that relates to everyday life, or the other aforementioned topics, which is then studied either in laboratory conditions or based on provided results. This framework was constructed by applying Gilbert's (2006) four-level context model and Aikenhead's (1994) eight-step STS model.

\subsection{Research subject}

The analysis was conducted on the experiment instructions found in three commonly-used upper secondary school textbook series that meet the current curricular requirements (FNBE 2003). The three textbook series in question (Kaila 2005a, b, c, d, e; Lehtiniemi \&Turpeinen 2005a, b, c, d, e; Lampiselkä \&al. 2004a, b, c, d, e) amount to most of the sold copies of upper 
secondary school chemistry textbooks in Finland. Each series contained five volumes. The total number of analysed experiment instructions was $160(\mathrm{~N}=160)$.

\subsection{Data analysis}

Aikenhead's (1994) steps were applied by organising the studied content into levels 0, I and II with the following meanings: (0) no context, (I) indirect contextual references (Aikenhead's step 1) and (II) context-based experiment instructions (Aikenhead's steps 28). If experiment instructions had features of both level I and level II, they were considered to be level II.

More detailed definition of the levels:

\section{LEVEL 0}

The experiment instructions have no context or the context does not refer to everyday life or any of the other defined themes.

\section{LEVEL I}

Level I experiment instructions have a merely motivational context-based element from everyday life that has nothing to do with the experiment itself, but refers to another event or phenomenon. Examples of such references are:

(a) The instructions mention an everyday-life issue or definition that is unrelated to the purpose of the experiment.

(b) The instructions use a chemical, such as household sugar, that is familiar to the student, but do not tie it to a context.

(c) Questions at the end of the experiment that refer to everyday life.

(d) The instructions have a picture that refers to everyday life.

\section{LEVEL II}

Experiment instructions use a context-based approach. They connect the phenomenon they discuss to a context. The beginning of the instructions describes the topic of the experiment. The purpose of the experiment could be the study of the presented everyday phenomenon, for example. There are differences in the scope of the context:

(a) The purpose and realisation of the experiment may consist of simply identifying the proteins in a foodstuff, for example.

(b) The context is probed more deeply in experiment instructions that first discuss the presence of nickel in jewellery and the related health issues, and then instruct the learner to study if the presented jewellery contains nickel, for example.

\subsection{Results}

The distribution of the 160 experiment instructions into the three levels may be seen in Figure 1. Level 0 was the largest group and it contained 60 instructions, which is over one 
third of the total (37.5\%). Level 0 instructions had no context or references to everyday life or the other defined themes.

The second langest group was level II, which contained 57 instructions, or approximately one third of the total (35.6\%). These experiments were context-based and they were connected to everyday life or the other defined themes.

This leaves 43 instructions in the level I group, less than one third of the total (26.9\%). Level I instructions only contained indirect references to everyday life.

The kappa value of the classification was $0.85(\mathrm{~N}=40)$.

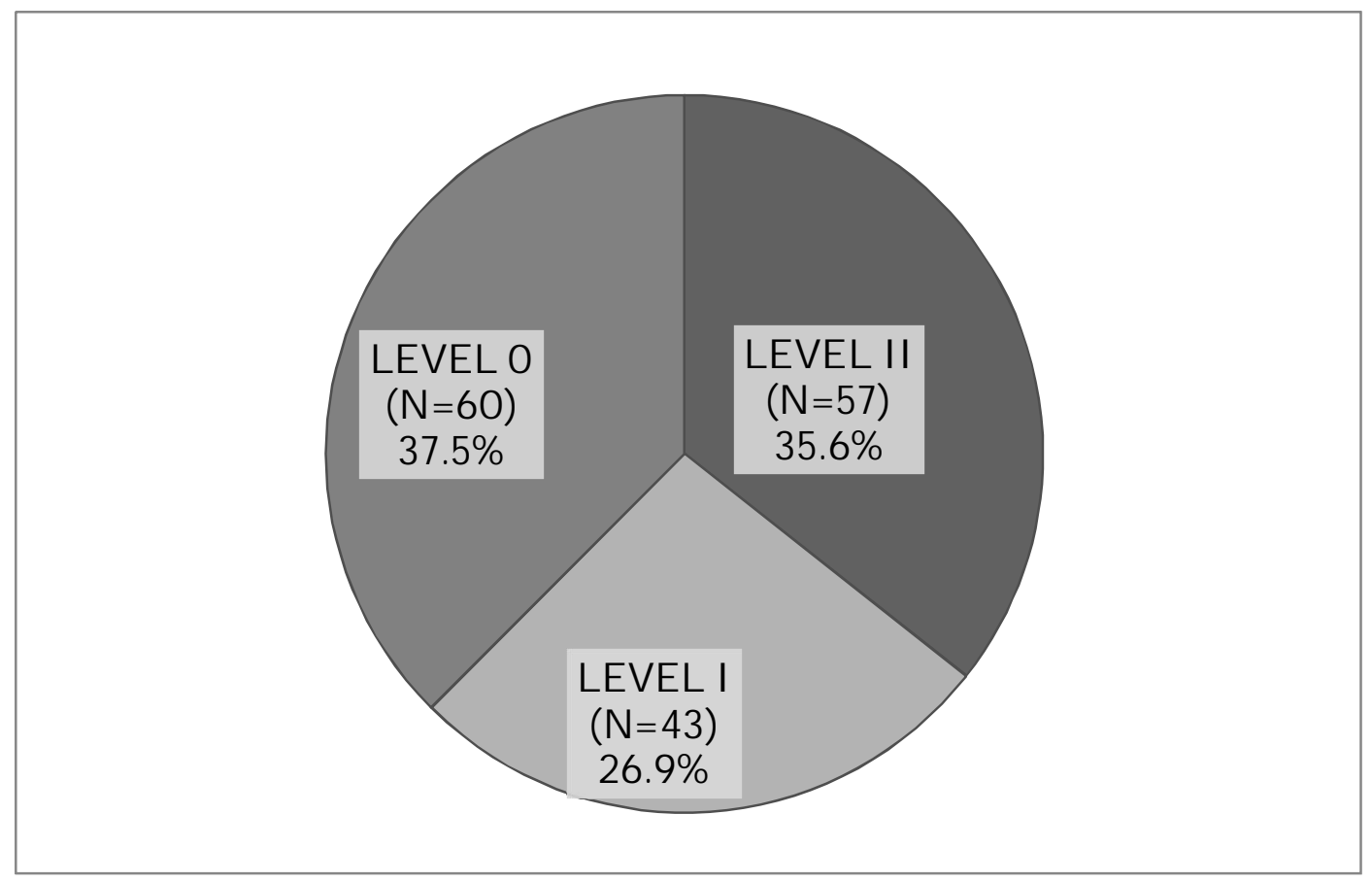

Figure 1 Distribution of experiment instructions into the three different levels

The analysis also focused on the themes discussed in the experiment instructions. The themes could be divided into five categories that arose from the data (see Table 1). One experiment's instructions could contain more than one theme. These themes were:

1. Home economics

2. Environment and nature

3. Industry, technology and production

4. Human biology and health

5. Culture and history

The most oommon category was home economics, which was present 86 times. The largest subcategory within home economics was food and foodstuffs, which were present in 53 instructions. This theme was the most popular one by far. This subcategory also included foodstuff-related studies and the use of kitchen chemicals, such as baking powder. General use items, another subcategory, included nails and razor blades, for example. The subcategory of everyday chemicals included, for example, cleaning and bleaching agents. 
Table 1 Distribution of instruction themes in the five main categories

\begin{tabular}{lccc}
\hline Home economics (N=86) & TOTAL & LEVEL I & LEVEL II \\
\hline Food and foodstuffs & 53 & 27 & 26 \\
General use items & 19 & 12 & 7 \\
Everyday chemicals & 14 & 5 & 9 \\
\hline Environment and nature (N=17) & & & \\
Nature and environment & 8 & 4 & 4 \\
Environmental hazards and protection & 6 & 3 & 3 \\
Animals and pets & 3 & 3 & 0 \\
Industry, technology and production (N=17) & & & \\
Fuels & 6 & 6 & 0 \\
Materials & 4 & 0 & 4 \\
Chemical industry & 4 & 3 & 1 \\
Agriculture & 2 & 2 & 0 \\
Transportation & 1 & 1 & 0 \\
\hline Human biology and health (N=16) & & & \\
Medical substances & 7 & 2 & 5 \\
Body chemistry & 7 & 7 & 0 \\
Health & 2 & 0 & 2 \\
\hline Culture and history (N=7) & & & \\
History & 6 & 6 & 0 \\
Art & 1 & 0 & 1 \\
\hline
\end{tabular}

The environment and health category included themes related to plants, animals and environmental protection. These appeared a total of 17 times in the studied instructions. The included themes were related to insects and minerals in the soil, for example. Testing the purity of well water is an example of an environmental protection theme.

Themes related to industry, technology and production occurred 17 times. Fuels were placed in this category because they are connected to technology and transportation. This category represented fuels, materials, the chemical industry, agriculture and transportation, and included such themes as petrol, metal pickling, cars, the use of fertilizers and the manufacture of fragrances.

Human biology and health were present in 16 instructions. This category represented medical substances, body chemistry and health conditions, and included such themes as aspirin synthesis, the formation of urea and nickel allergy.

Culture and history were included in seven instructions. The development history of the breathalyser is an example of a historical theme and the one art theme was the analysis of forgeries using spectroscopy 


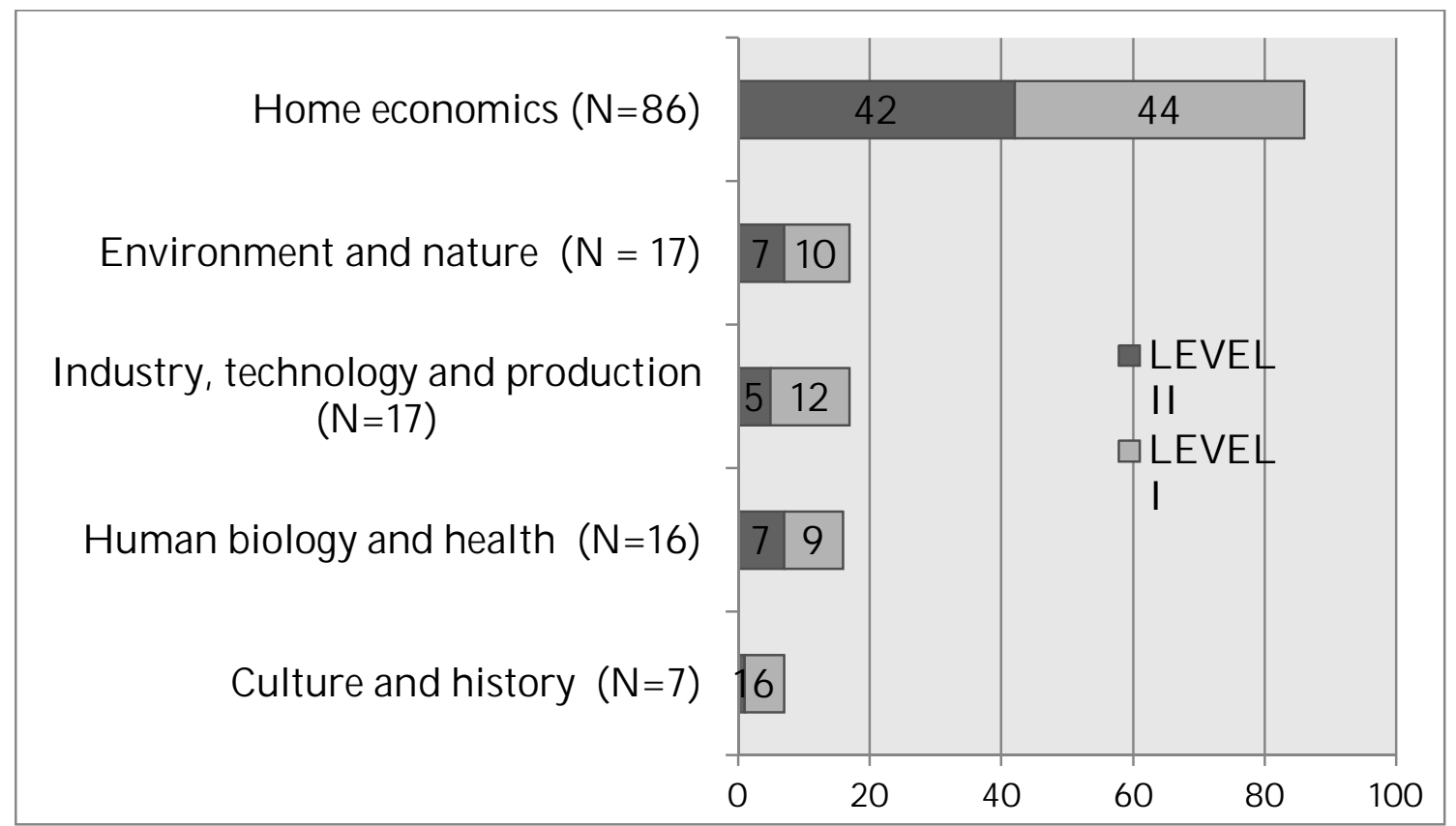

Figure 2 Distribution to levels I and II within the five categories

When viewed as a bar graph (Figure 2), the distribution of themes into context levels I and II is nearly even, with slight emphasis on level I. The categories of industry, technology and production and culture and history are the exception, as they clearly lean towards level I.

\section{Conclusions and reflection}

The application of Gilbert's (2006) four-level context model revealed that most of the experiment instructions were "recipe-like" and on the first level of the model, with some exceptions. Nearly all instructions, barring a few exceptions, were lacking in scientific inquiry.

The analysis revealed that the application of Aikenhead's (1994) eight-step STS model was not optimal for the purposes of this study because the level of contextuality varied in the instructions. Contextuality could not be clearly demonstrated in percentages in relation to STS content and theory. Additionally, the eight-step scale could not be used as such because Aikenhead's higher steps are already thought to contain Gilbert's levels 2, 3 and 4. These levels were almost completely absent in the data. Therefore, the categorisation was simplified to three levels: 0, I and II.

The fact that the context distribution very strongly favoured home economics could be explained by the easy availability of the ingredients and raw materials. These materials are also safe and affordable. However, one could also conclude that the contexts have emphasized just one aspect of everyday life too heavily while neglecting the others.

The distribution of the contexts into levels and categories suggests that the emphasis is largely on the individual level of relevance, as defined by Stuckey \& al. (2013). Level 0 experiment instructions aim to teach the theoretical content of the course and they may be considered to belong to the individual dimension. Most of the themes in the largest category, home economics, were also mostly individual in nature and very few, if any, of the 
instructions in this category contained societal or vocational dimensions. The societal dimension was present in the themes related to environmental protection. A vocational element could be found in the themes related to agriculture, medical scienceand the chemical industry, for example. On the other hand, every experiment can be considered to have a vocational element, as the students are practicing a chemist's laboratory skills as they conduct them.

The results indicate that there is a need to diversify the contexts and relevance of experiment instructions. Considering the results of the ROSE study, the instructions were lacking in the issues the youth found interesting: decision-making, opportunities to make a difference, developing themselves and helping others. Contextuality is not self-evident in the current material, and when there is a context, the themes are one-sided. The instructions are also largely recipe-like and they demonstrate very little scientific inquiry. The nature of science and higher order thinking skills are also absent.

There are no direct comparisons in research literature between the experiments found in Finnish textbooks and those found in textbooks elsewhere. However, it can be stated that the context-based approach of instructions for experimental tasks is also emerging and being developed outside of Finland as well, and there is a need for it. The STS-based Salters' programme in the United Kingdom, for example, has reported results of higher motivation and interest in chemistry careers when compared to traditional teaching (Bennett \&Lubben 2006). The Industrial Chemistry programme in Israel focuses on career choices and societal significance (Hofstein \& Kesner 2006), and the Chemistry in Practice programme in the Netherlands focuses on the context of water quality, for example (Bulte \& al. 2006). These programmes also take into account the societal, technological and vocational levels in addition to theindividual level, as STS approaches are supposed to do. 


\section{References}

Aikenhead, G. S. (1994). Consequences to learning science through STS: A research perspective. In J . Solomon \& G. Aikenhead (Eds.), STS education: International perspectives on reform (pp. 169186). New York, NY: Teachers College Press, 169-186.

Aikenhead, G. S. (2003). Review of research on humanistic perspectives in science curricula. Paper presented at the ESERA conference, Nordwijkerhoud, The Netherlands.

Aroluoma, I., Kanerva, K., Karkela, L., Lampiselkä, J., Mäkelä, R., Sorjonen, T. \&Vakkilainen, K-M. (2005a). Kemisti 1. Porvoo: Werner Söderström Oy.

Aroluoma, I., Kanerva, K., Karkela, L., Lampiselkä, J., Mäkelä, R., Sorjonen, T. \& Vakkilainen, K-M. (2005b). Kemisti 2. Porvoo: Werner Söderström Oy.

Aroluoma, I., Kanerva, K., Karkela, L., Lampiselkä, J., Mäkelä, R., Sorjonen, T. \& Vakkilainen, K-M. (2005c). Kemisti 3. Porvoo: Werner Söderström Oy.

Aroluoma, I., Kanerva, K., Karkela, L., Lampiselkä, J., Mäkelä, R., Sorjonen, T. \& Vakkilainen, K-M. (2005d). Kemisti 4. Porvoo: Werner Söderström Oy.

Aroluoma, I., Kanerva, K., Karkela, L., Lampiselkä, J., Mäkelä, R., Sorjonen, T. \&Vakkilainen, K-M. (2005e). Kemisti 5. Porvoo: Werner Söderström Oy.

Bennett, J ., \&Lubben, F. (2006). Context-based chemistry: The Salters approach. International J ournal of Science Education, 28, 999- 1015.

Bulte, A. M. W., Westbroek, H. B., deJ ong, O. \&Pilot, A. (2006). A Research Approach to Designing Chemistry Education using Authentic Practices as Contexts. International J ournal of Science Education, 28, 1063- 1086.

Edelson, D. C. (2002). Design Research: What We Learn When We Engage. Design J ournal of the Learning Sciences, 11, 105- 121.

Gilbert J. K. (2006). On the nature of "context" in chemical education. International J ournal of Science Education, 28, 957-976.

Hofstein, A., Eilks, I. and Bybee, R. (2010). Societal Issues and Their Importance for Contemporary Science Education. I. Eilks \& B. Ralle (Eds.) Contemporary science education (pp. 5- 22). Aache: Shaker.

Hofstein, A. \& Kesner, M. (2006). Industrial chemistry and school chemistry: Making chemistry studies more relevant. International J ournal of Science Education, 28, 1017- 1039.

Juntunen, M. K. \&Aksela, M. K. (2014). Education for sustainable development in chemistry challenges, possibilities and pedagogical models in Finland and elsewhere. Chemistry Education Research and Practice, 15, 488- 500

Kuhn, J . \& Müller A. (2014). Text-based Science Education by Newspaper Story Problems: A Study on Motivation and Learning Effects. Perspectives in Science, 2, 5- 21.

Kaila, L., Meriläinen, P., Ojala, P., Pihko, P., \& Salo, K. (2005a). Reaktio 1. Jyväskylä: Kustannusosakeyhtiö Tammi.

Kaila, L., Meriläinen, P., Ojala, P., \& Pihko, P. (2005b). Reaktio 2.J yväskylä: Kustannusosakeyhtiö Tammi.

Kaila, L., Meriläinen, P., Ojala, P., \& Pihko, P. (2005c). Reaktio 3. Jyväskylä: Kustannusosakeyhtiö Tammi.

Kaila, L., Meriläinen, P., Ojala, P., \& Pihko, P. (2005d). Reaktio 4. Jyväskylä: Kustannusosakeyhtiö Tammi.

Kaila, L., Meriläinen, P., Ojala, P., \& Pihko, P. (2005e). Reaktio 5. Jyväskylä: Kustannusosakeyhtiö Tammi.

Lavonen, J ., J uuti, K, Uitto, A., Meisalo, V. \& Byman, R. (2005). Attractiveness of Science Education in the Finnish Comprehensive School. In A. Manninen, K. Miettinen \& K. Kiviniemi (Eds.), Research Findings on Young People's Perceptions of Technology and Science Education. Mirror results and good practice. Helsinki: Technology Industries of Finland. 
Lehtiniemi, K., \&Turpeenoja, L. (2005a). Mooli 1. Keuruu: Kustannusosakeyhtiö Otava.

Lehtiniemi, K, \&Turpeenoja, L. (2005b). Mooli 2. Keuruu: Kustannusosakeyhtiö Otava.

Lehtiniemi, K., \& Turpeenoja, L. (2005c). Mooli 3. Keuruu: Kustannusosakeyhtiö Otava.

Lehtiniemi, K. \&Turpeenoja, L. (2005d). Mooli 4. Keuruu: Kustannusosakeyhtiö Otava.

Lehtiniemi, K, \&Turpeenoja, L. (2005e). Mooli 5. Keuruu: Kustannusosakeyhtiö Otava.

OPH (2003). Lukion opetussuunnitelman perusteet 2003, Vammala: Opetushallitus.

Stolk, M.J., Bulte, A.M.W., de Jong, O. \& Pilot, A. (2009). Towards a framework for a professional development programme: empowering teachers for context-based chemistry education. Chemistry Education Research and Practice, 10,164- 175.

Stuckey M., Hofstein A., Mamlok-Naaman R. \& Eilks I. (2013). The meaning of 'relevance' in science education and its implications for the science curriculum. Studies in Science Education, 49, 1- 34.

Ültay, N. \& Çalik, M. (2012). A Thematic Review of Studies into the Effectiveness of Context-Based Chemistry Curricula. J ournal of Science Education and Technology, 21, 686- 701

Vesterinen, V-M, Aksela, M. \& Lavonen, J . (2011). Quantitative Analysis of Representations of Nature of Science in Nordic Upper Secondary School Textbooks Using Framework of Analysis Based on Philosophy of Chemistry. Science \&Education, 22, 1839-1855.

Wilkinson, J . (1999). A Quantitative Analysis of Physics Textbooks for Scientific Literacy Themes. Research in Science Education, 29, 385-399. 